\title{
Effect of different proportions of popped amaranth grain (Amaranthus cruentus) as an iron supplement in piglet diets on selected blood indicators
}

\author{
Miroslav I. Urosevic ${ }^{1}$, Isabel Hennig-Pauka ${ }^{2}$, Alexander Tichy ${ }^{3}$, Nenad Stojanac $^{4}$, \\ Radomir Ratajac ${ }^{5}$
}

\begin{abstract}
${ }^{1}$ Scientific Institute of Reproduction and Artificial Insemination for Domestic Animals, “Temerin”, Serbia ${ }^{2}$ University of Veterinary Medicine Vienna, University Clinic for Swine, Department for Farm Animals and Veterinary Public Health,

${ }^{3}$ Platform Bioinformatics and Biostatistics, Department of Biomedical Sciences, Vienna, Austria ${ }^{4}$ University of Novi Sad, Department of Veterinary Medicine, Faculty of Agriculture, Novi Sad, Serbia ${ }^{5}$ Scientific Veterinary Institute "Novi Sad", Novi Sad, Serbia
\end{abstract}

Received September 8, 2014

Accepted April 1, 2015

\begin{abstract}
The aim of our study was to compare the effect of various proportions of popped amaranth grain (Amaranthus cruentus) in piglet diets on selected blood indicators, such as red blood cell count (RBC), haematocrit (HCT), haemoglobin concentration (HB) and mean corpuscular haemoglobin concentration (MCHC), but also growth efficiency (daily weight gain) and tissue morphology of the gastrointestinal tract. Altogether, 122 piglets (12 litters) were divided randomly into four groups $(4 \times 3$ litters $)$. Diet of the piglets in the control group was without popped amaranth grain. Starting from day 5 until day 90 of life, each of the three experimental groups was offered one of the feed mixtures containing different amounts of heat-treated popped amaranth grain: 20\% (group A20), 40\% (group A40), and $79 \%$ (group A79). When comparing the three experimental groups with the control group, in relation to the mean haemoglobin concentration and red blood cell count, higher values were measured in almost all periods of the piglets' life, except for five-day-old piglets in the experimental groups. Only in 90-day-old piglets, group A79 tended to have a higher body weight compared to the control piglets. In summary, differences in haematologic indices which occurred between groups were inconsistent and of minor practical impact. With regard to the costs of the Amaranthus diet, beneficial effects were not obvious.
\end{abstract}

Swine, nutrition, anaemia, iron deficiency, haematocrit, haemoglobin

The most frequently used method to meet the needs and prevent anaemia in suckling piglets is administration of $\mathrm{Fe}^{3+}$ in the form of dextran (Svoboda et al. 2004). Svoboda and Drabek (2002) concluded that piglets should have iron (Fe) administered before day 6 after their birth to prevent anaemia. However, parenteral administration of iron to piglets after birth is not always free of health risks. Some authors, e.g. Heinritzi and Plonait (1997), claim that a high supply of iron can contribute to development of bacteraemia. Holmgren (1996) reported a more frequent occurrence of polyarthritis in parentally Fe-dosed piglets. According to Lehmann (2001), the negative impact of parenterally administered $\mathrm{Fe}^{3+}$ causes the inhibition of macrophages, weakening their phagocytic abilities. The effects of piglet consumption of solid mineral supplements differ. As the absorption of $\mathrm{Fe}^{2+}$ is much better than that of $\mathrm{Fe}^{3+}$ (Dietzfelbinger 1987), only preparations containing bivalent iron are used for paste production. Lactate is a compound with sufficiently high concentration of $\mathrm{Fe}^{2+}$ ions necessary for oral administration. The bond of Fe to organic acids commonly present in animals is an advantage (Svoboda et al. 2004). However, Dubansky et al. (1997) and Egeli and Framstad (1998) considered the use of solid mineral supplements as problematic, due to the low consumption of solid 
feed in the first two weeks of the piglets' life. Unfortunately, references concerning the prevention and therapy of pig anaemia with special nutrition which could influence blood indicators and health status of piglets are scarce.

The Andean crop amaranth is a pseudo cereal that has been the focus of attention in many scientific studies over the last two decades, mainly because of its nutritional, functional, agricultural, and technological potential (Zraly et al. 2006; Bartkowiak et al. 2007; Kroliczewska et al. 2008; Ferreira and Areas 2010). The genus Amaranthus belongs to the family Amaranthaceae and includes more than 60 species. An additional benefit is that amaranth contains many minerals, such as calcium, sodium, iron, magnesium and vitamin E (Yanez et al. 1994). The use of amaranth has become prevalent after the ban on animal-derived feeds in animal nutrition, and concern was expressed as to what substances to use in order to replace the high-quality raw material previously used for the preparation of combined feeds without producing adverse effects on the health status and performance of fattened pigs (Zraly et al. 2006). Pisarikova et al. (2005) determined the nutritional value (chemical composition, amino acid content, in vitro protein digestibility) of raw and heat-treated popped amaranth grain in feed mixtures for broiler chickens. The high content of crude protein, favourable composition of amino acids and fibre and high coefficients of nutrient digestibility in a diet with $10 \%$ of raw popped amaranth grain predicated these substances as suitable supplements to conventional feeds in feed mixtures for broiler chickens (Pisarikova et al. 2005).

Since amaranth poppy grain contains non-nutritional ingredients, heat-treated $(30 \mathrm{~s}$ at $160{ }^{\circ} \mathrm{C}$ ) popped amaranth grain (PAG) has been used for animal feed (Correa et al. 1986; Imeri et al. 1987). However, up-to-date data on the use of amaranth in pig nutrition are scarce (Sokol et al. 2001; Zraly et al. 2004). Zraly et al. (2004) investigated whether it would be possible to substitute amaranth for proteins of animal origin in the pig diet, using one type of feed ration during the entire period of fattening, and followed its impact on the pigs' growth efficiency and health, carcass characteristics and meat quality. These authors concluded that the high contents of lipids and essential fatty acids, particularly linoleic acid and squalene, in amaranth may be effective in wholesome pork production due to modification of the fatty acid composition of meat. Amaranth accumulates Fe to much higher concentrations than many other widely available cultivated green leafy vegetables (GLVs) (Ifon and Bassir 1978; Makus 1984; Chawla et al. 1988). Rangarajan et al. (1998) studied Fe bioavailability from amaranth using haemoglobin (HB) repletion in anaemic rats. When amaranth $(30 \mathrm{mg} / \mathrm{kg}$ diet $)$ was added to individual diets, analysis of HB repletion efficiency indicated that $A$. tricolor supported the largest HB gain of the three lines studied, despite having the lowest relative Fe bioavailability compared to A. hypochondriacus and $A$. cruentus.

The aim of our study was to compare the effect of various proportions of popped amaranth grain (Amaranthus cruentus) in piglet diets on selected blood indicators, as red blood cell count (RBC), haematocrit (HCT), haemoglobin concentration (HB) and mean corpuscular haemoglobin concentration (MCHC), but also growth efficiency (body weight gain and daily weight gain) and tissue morphology of the gastrointestinal tract.

\section{Materials and Methods}

Animals

The study involved 12 sows from one commercial pig farm in Serbia, which held approximately 20000 fattened pigs (Yorkshire $\times$ Swedish Landrace). Blood samples were taken from 12 animals (sows, approximately 100 day of gestation), pre-selected according to clinical signs of suspected anaemia. Haematological examination of the 12 blood samples showed that the 12 sows selected for the study were anaemic. The classification criteria for anaemia were the values below which we considered the animals anaemic: $\mathrm{RBC}<5.8 \mathrm{~T} / 1$ and/or $\mathrm{HB}<108 \mathrm{~g} / \mathrm{l}$. The sows were housed on-farm in standard commercial conditions. Sows were transferred into farrowing pens a fortnight before parturition and stayed there until piglets were weaned at the age of 28 days. 
Altogether, 122 piglets (12 litters) were divided randomly into four groups $(4 \times 3$ litters $)$. Group $1(\mathrm{~K}+\mathrm{P})$ was the control group and contained 33 piglets, group 2 (A20) contained 33 piglets, group 3 (A40) contained 29 piglets and group 4 (A79) contained 27 piglets. All the animals were marked by tattooing and also with ear tags. Iron supplement injections were not administered to any of the piglets, and none of the male piglets was castrated.

\section{Feeding}

Popped amaranth grain was heat-treated for $30 \mathrm{~s}$ at $160{ }^{\circ} \mathrm{C}$, and then mixed into a pig feed based on wheat grain, skimmed cow's milk powder, supplemented with a vitamin and mineral premix. Mixed piglet feeds finally contained 20, 40 or $79 \%$ of PAG. The diet of piglets in the control group $1(\mathrm{~K}+\mathrm{P})$ was based on maize grain and oil, wheat grain and skimmed cow's powder, but without PAG. Piglet diets and iron concentrations in the feeds are shown in Table 1. Starting from the fifth day of life until the end of the study, each experimental group of piglets was offered one of the feed mixtures containing amaranth, while control piglets were offered the diet with no PAG.

The iron content was determined in feed by atomic absorption spectrophotometry using the Varian Spectra AA10 (Varian Techtron, Mulgrave Victoria, Australia; FAO 1980). Each group of piglets was fed twice per day from day 5 to day 90. Water was available ad libitum. The piglets were weighed on days 5 (the day of birth was taken as day 0$), 10,28,60$ and 90 of life. The health status of animals was monitored daily by a competent veterinarian at the farm through observation at regular intervals. Morbidity and mortality, which occurred occasionally, were recorded.

Table 1. Composition of the diets (\%) and iron content $(\mathrm{mg} / \mathrm{kg})$.

\begin{tabular}{|c|c|c|c|c|}
\hline Ingredient & $\begin{array}{l}\text { Control } \\
\mathrm{K}+\mathrm{P} \text { group } \\
\text { (Diet } 1)\end{array}$ & $\begin{array}{c}\text { PAG - } 20 \% \\
\text { A20 group } \\
\text { (Diet } 2 \text { ) }\end{array}$ & $\begin{array}{c}\text { PAG - } 40 \% \\
\text { A40 group } \\
\text { (Diet } 3 \text { ) }\end{array}$ & $\begin{array}{c}\text { PAG - 79\% } \\
\text { A79 group } \\
\text { (Diet 4) }\end{array}$ \\
\hline Amaranth poppy grain & - & 20 & 40 & 79.61 \\
\hline Wheat grain & 20 & 38.07 & - & - \\
\hline Wheat bran & 4 & - & - & - \\
\hline Maize grain & 35.47 & - & 25.19 & - \\
\hline Maize oil & 2.16 & - & - & - \\
\hline L-lysine $(78 \%)$ & 0.12 & - & - & 0.16 \\
\hline DL methionine (99\%) & 0.02 & - & - & 0.10 \\
\hline Skimmed cow milk powder & 10.01 & 40.73 & 33.61 & 18.81 \\
\hline Dicalcium phosphate $(17 \% \mathrm{P})$ & 0.79 & - & - & - \\
\hline Extracted soybean meal (44\%) & 14 & - & - & - \\
\hline Soybean grits $(38-19.5)$ & 12 & - & - & - \\
\hline Salt - sodium chloride (with iodine) & 0.21 & - & - & 0.12 \\
\hline Livestock chalk & 0.03 & - & - & - \\
\hline \multicolumn{5}{|l|}{ Vitamin and mineral premix } \\
\hline PAN-O-VIT-PRASE $1 \%$ (Patent-Co, Serbia)* & 1.20 & 1.20 & 1.20 & 1.20 \\
\hline Sodium chloride & 0.12 & - & - & - \\
\hline $\bar{\Sigma}$ & 100 & 100 & 100 & 100 \\
\hline Iron concentration in diet ( $\mathrm{mg} / \mathrm{kg})$ & 327.98 & 237.67 & 248.54 & 285.10 \\
\hline Cost of feed/1 kg (EUR) & 0.45 & 0.69 & 0.78 & 0.94 \\
\hline Cost of feed/30 kg (EUR) & 13.5 & 20.7 & 23.4 & 28.2 \\
\hline
\end{tabular}

*PAN-O-VIT-PRASE 1\% (Patent-Co, Serbia), composition: vitamin A, E 672 (1,540,000 IU/kg), vitamin D, E $671(200,000 \mathrm{IU} / \mathrm{kg})$; vitamin E (10,000 IU/kg); vitamin K3 (200 mg/kg), vitamin B1 (200 mg/kg), vitamin B2 $(760 \mathrm{mg} / \mathrm{kg})$, pantothenic acid $(2500 \mathrm{mg} / \mathrm{kg})$, vitamin B6 $(500 \mathrm{mg} / \mathrm{kg})$, niacin $(4000 \mathrm{mg} / \mathrm{kg})$, folic acid $(150 \mathrm{mg} / \mathrm{kg})$, vitamin B12 $(5 \mathrm{mg} / \mathrm{kg})$, biotin $(24 \mathrm{mg} / \mathrm{kg})$, choline $(45,000 \mathrm{mg} / \mathrm{kg})$, zinc E6 $(13,000 \mathrm{mg} / \mathrm{kg}), \mathrm{copper}$ $(3150 \mathrm{mg} / \mathrm{kg})$, iron E1 $(12,500 \mathrm{mg} / \mathrm{kg})$, manganese E5 $(5500 \mathrm{mg} / \mathrm{kg})$, iodine $(160 \mathrm{mg} / \mathrm{kg})$, selenium $(40 \mathrm{mg} / \mathrm{kg})$, cobalt E3 (42 mg/kg), calcium (minimum 30\%).

$02 \%$ : zinc oxide

IU - International Unit 


\section{Haematology}

Blood samples $(3 \mathrm{ml})$ were collected from the piglets on days $5,10,28,60$, and 90 by puncture of the cranial vena cava, using ethylene-diamine-tetra-acetic acid (EDTA) as anticoagulant. The following haematological values were determined in blood samples: $\mathrm{RBC}, \mathrm{HCT}, \mathrm{HB}, \mathrm{MCHC}$. The haematological measurements were made with an ABACUS JUNIOR VET (Diatron MI PLC; Budapest, Hungary).

\section{Histopathology}

Out of 122 piglets included in the study, 29 were examined post mortem ( 25 piglets which were sacrificed and four which died during the study). Samples of the ventriculum, duodenum, jejunum, colon transversum, liver, mesenterial lymph nodes and pieces of the breastbone were taken for histopathological examination. Standard procedure included: fixation with neutral $10 \%$ formalin, embedding in paraffin, harvesting from five to ten histological cuts of $5 \mu \mathrm{m}$ thickness, and staining with haematoxylin eosin. The stained tissue slices were analysed by light microscopy.

\section{Animal welfare}

This study was approved by the Ethics Committee for Animal Experiments of the University of Novi Sad, Serbia (No. IV-2011-3 from 30.01.2012). Animals were kept, fed and sacrificed according to the standards recommended and accepted by the Animal Welfare Law of the Republic of Serbia and Animal Research Regulations of the University of Novi Sad.

\section{Statistical analyses}

Data were analyzed using IBM SPSS software version 20 (SPSS Inc., Chicago, IL, USA). Results are reported as means and standard deviation at the $95 \%$ confidence interval. Differences in means between groups were analyzed using a general linear model and also repeated measurements ANOVA for HB, RBC, MCHC, and HCT. For all indicators, differences from the control-group indicators were analyzed using Dunnett's post hoc procedure. Also, 95\%-confidence intervals were calculated to show whether the observed mean value of an indicator lay significantly below or above a specific norm. The assumption of normal distribution was controlled using Kolmogorov-Smirnov test. For all statistical analyses $P<0.05(5 \%)$ was regarded as significant, and $P<0.01(1 \%)$ was regarded as highly significant.

\section{Results}

\section{Haematological indicators}

Over time, significant changes in haematological indices were observed in all groups of piglets. Data of selected indicators are shown group-wise in Tables 2 to 5. In Table 6 significant differences between sampling times, which were similar in all groups, are indicated.

When comparing three experimental groups with the control group, in relation to the mean $\mathrm{HB}$ concentration and $\mathrm{RBC}$ count, higher values were measured in almost all periods of the piglets' life (mainly group A79), except for five-day-old piglets in the experimental groups. This is shown in Tables 2 and 3. Comparison of HCT and MCHC in the three experimental groups with the control group showed that, in all periods of piglet life, in almost all cases, higher values were detected in group A79 than in the control piglets (Tables 4 and 5).

Significant differences were detected in HB concentration in the blood of piglets in the control group and in group A79 on several examination days $(P=0.011)$.

\section{Body weight}

The mean body weights on days $5,10,28,60$, and 90 and the mean daily weight gain of the piglets are presented in Table 7.

The body weight and mean daily weight gain were significantly higher in the control piglets, compared to the other three groups of piglets. The control piglets had higher body weights compared to the experimental piglets from the beginning of the study until the $60^{\text {th }}$ day of the piglets' life. At the end of the study, piglets of group 3 (A40) had the highest body weight. In 90-day-old piglets, group A79 tended to have a higher body weight 
compared to the control piglets (Table 7). The mixed feed prepared for the control piglets contained the highest Fe concentration; while in the other three amaranth-containing feeds, Fe concentrations were significantly lower (Table 1).

Table 2. Blood haemoglobin concentration $(\mathrm{g} / \mathrm{l})$ in the peripheral blood of piglets during the study and from published literature - descriptive statistical values.

\begin{tabular}{|c|c|c|c|c|c|c|c|}
\hline Indicator & Group & Stat. value & Day 5 & Day 10 & Day 28 & Day 60 & Day 90 \\
\hline \multirow[t]{4}{*}{$\begin{array}{l}\text { Reference } \\
\text { range }(g / l)\end{array}$} & $\begin{array}{l}\text { Egeli et al. } \\
\text { (1998) }\end{array}$ & Mean & 81 & 102 & - & - & - \\
\hline & Nerbas & Mean & $75.12-$ & $75.12-$ & $75.12-$ & $90.11-$ & 90.11- \\
\hline & (2008) & & 139.12 & 139.12 & 139.12 & 137 & 137 \\
\hline & $\begin{array}{l}\text { Kixmoller } \\
(2004)\end{array}$ & Mean & - & - & - & $\begin{array}{l}106.4- \\
145\end{array}$ & $\begin{array}{l}106.4- \\
145\end{array}$ \\
\hline \multirow{16}{*}{$\mathrm{HB}$} & & Mean $( \pm$ SD $)$ & $\begin{array}{l}85.41 \\
(10.74)\end{array}$ & $\begin{array}{l}67.54 \\
(14.89)\end{array}$ & $\begin{array}{l}60 \\
(22.87)\end{array}$ & $\begin{array}{l}97.26 \\
(8.09)\end{array}$ & $\begin{array}{l}106.27 \\
(9.56)\end{array}$ \\
\hline & $\mathrm{K}+\mathrm{P}$ & Median & 86 & 69 & 63.50 & 99 & 106 \\
\hline & & Minimum & 65 & 41 & 23 & 77 & 90 \\
\hline & & Maximum & 109 & 97 & 103 & 111 & 125 \\
\hline & & Mean $( \pm \mathrm{SD})$ & $\begin{array}{l}85.03 \\
(13.41)\end{array}$ & $\begin{array}{l}62.38 \\
(8.80)\end{array}$ & $\begin{array}{l}47.36 \\
(9.23)\end{array}$ & $\begin{array}{l}86.66 \\
(16.60)\end{array}$ & $\begin{array}{l}107.66 \\
(9.70)\end{array}$ \\
\hline & A20 & Median & 84.50 & 64 & 48 & 82 & 108 \\
\hline & & Minimum & 54 & 37 & 31 & 67 & 87 \\
\hline & & Maximum & 113 & 79 & 63 & 132 & 125 \\
\hline & & Mean $( \pm \mathrm{SD})$ & $\begin{array}{l}77.28 \\
(7.39)\end{array}$ & $\begin{array}{l}65.84 \\
(9.88)\end{array}$ & $\begin{array}{l}58.21 \\
(24.30)\end{array}$ & $\begin{array}{l}116.43 \\
(13.40)\end{array}$ & $\begin{array}{l}108.22 \\
(6.23)\end{array}$ \\
\hline & A 40 & Median & 79 & 67 & 57 & 117.50 & 109 \\
\hline & & Minimum & 62 & 47 & 11 & 91 & 88 \\
\hline & & Maximum & 92 & 85 & 122 & 146 & 117 \\
\hline & & Mean $( \pm$ SD $)$ & $\begin{array}{l}85.11 \\
(6.14)\end{array}$ & $\begin{array}{l}81.39 \\
(12.76)\end{array}$ & $\begin{array}{l}79.66 \\
(29.48)\end{array}$ & $\begin{array}{l}113 \\
(13.88)\end{array}$ & $\begin{array}{l}108.82 \\
(8.35)\end{array}$ \\
\hline & A79 & Median & 85.50 & 82 & 79 & 110 & 109 \\
\hline & & Minimum & 75 & 59 & 36 & 90 & 97 \\
\hline & & Maximum & 99 & 102 & 118 & 143 & 124 \\
\hline
\end{tabular}

HB - blood haemoglobin concentration

$\mathrm{SD}$ - standard deviation

$\mathrm{K}+\mathrm{P}$ - control group, feed mixtures without popped amaranth grain

A20 - feed mixtures containing $20 \%$ of heat-treated popped amaranth grain

A40 - feed mixtures containing $40 \%$ of heat-treated popped amaranth grain

A79 - feed mixtures containing $79 \%$ of heat-treated popped amaranth grain

\section{Histopathology}

Macroscopic as well as microscopic findings did not differ between the different groups of piglets. All internal organs as well as all histological samples were free of any pathological findings.

Analysis of the piglet diets in our study showed that the highest concentration of iron in the mixtures was found in the feed for the control piglets $(327.98 \mathrm{mg} / \mathrm{kg})$, whereas the feeds for the other three piglet groups (A20, A40 and A79) contained proportionately less $\mathrm{Fe}(237.67,248.54$, and $285.10 \mathrm{mg} / \mathrm{kg}$, respectively). 


\section{Cost-benefit analysis}

Cost-benefit analysis revealed that feeding piglets PAG involved increased costs over that of the control feed. Feeding amaranth to piglets for the 90 days of the study entailed an additional cost of between $€ 7.20$ and $€ 14.70$ per piglet of $25 \mathrm{~kg}$ body weight.

Table 3. Red blood cell count (T/1) in the peripheral blood of piglets during the study and from published literature - descriptive statistical values.

\begin{tabular}{|c|c|c|c|c|c|c|c|}
\hline Indicator & Group & Stat. value & Day 5 & Day 10 & Day 28 & Day 60 & Day 90 \\
\hline \multirow[t]{7}{*}{$\begin{array}{l}\text { Reference } \\
\text { range }(\mathrm{T} / \mathrm{l})\end{array}$} & $\begin{array}{l}\text { Egeli et al. } \\
(1998)\end{array}$ & Mean & 3.85 & 3.85 & 5.35 & - & 5.79 \\
\hline & Nerbas & Mean & $3.47-$ & $3.47-$ & $3.47-$ & 5.79 & $5.27-$ \\
\hline & (2008) & & 6.65 & 6.65 & 6.65 & & 7.33 \\
\hline & Kixmoller & Mean & $3.8-5$ & 5.35 & 5.79 & $5.27-$ & $5.11-$ \\
\hline & $(2004)$ & & & & & 7.33 & 8.3 \\
\hline & & Mean $( \pm \mathrm{SD})$ & 4.37 & 4.50 & 4.98 & 6.85 & 6.91 \\
\hline & & & $(0.59)$ & $(0.78)$ & $(2.00)$ & $(0.54)$ & $(0.65)$ \\
\hline \multirow[t]{7}{*}{$\mathrm{K}+\mathrm{P}$} & & Median & 4.37 & 4.49 & 5.30 & 6.94 & 6.95 \\
\hline & & Minimum & 2.93 & 2.81 & 1.59 & 5.64 & 5.46 \\
\hline & & Maximum & 5.66 & 5.80 & 8.12 & 7.65 & 8.29 \\
\hline & & Mean $( \pm$ SD $)$ & 4.36 & 4.04 & 4.85 & 6.95 & 6.99 \\
\hline & & & $(0.81)$ & $(0.81)$ & (1.01) & $(1.20)$ & $(0.45)$ \\
\hline & A20 & Median & 4.30 & 4.19 & 5.05 & 6.77 & 6.95 \\
\hline & & Minimum & 2.91 & 1.90 & 2.93 & 5.94 & 6.26 \\
\hline \multirow[t]{11}{*}{$\mathrm{RBC}$} & & Maximum & 6.15 & 5.10 & 6.21 & 11.34 & 8.15 \\
\hline & & Mean $( \pm$ SD $)$ & 3.96 & 3.97 & 4.50 & 6.28 & 6.98 \\
\hline & & & $(0.45)$ & $(0.54)$ & (1.48) & $(1.54)$ & $(0.48)$ \\
\hline & A40 & Median & 3.99 & 3.99 & 4.80 & 6.26 & 6.93 \\
\hline & & Minimum & 3.03 & 2.85 & 1.80 & 4.43 & 5.91 \\
\hline & & Maximum & 4.69 & 4.78 & 7.20 & 8.96 & 7.81 \\
\hline & & Mean $( \pm \mathrm{SD})$ & 4.36 & 4.49 & 5.57 & 7.13 & 6.96 \\
\hline & & & $(0.50)$ & $(0.47)$ & (1.38) & $(3.39)$ & $(0.42)$ \\
\hline & A79 & Median & 4.27 & 4.45 & 5.77 & 6.05 & 7 \\
\hline & & Minimum & 3.48 & 3.83 & 2.27 & 3.75 & 5.95 \\
\hline & & Maximum & 5.26 & 5.64 & 7.67 & 14.90 & 7.65 \\
\hline
\end{tabular}

RBC - red blood cell count

$\mathrm{SD}$ - standard deviation

$\mathrm{K}+\mathrm{P}$ - control group, feed mixtures without popped amaranth grain

A20 - feed mixtures which contained $20 \%$ of heat-treated popped amaranth grain

A40 - feed mixtures which contained $40 \%$ of heat-treated popped amaranth grain

A79 - feed mixtures which contained $79 \%$ of heat-treated popped amaranth grain

\section{Discussion}

In the current study, piglet diets with PAG contained less iron than the diet without PAG. However, another important factor, that may have played a role in the fact that the piglet diets containing PAG were not as effective as was hypothesised, was the lower bioavailability of iron in the PAG-based diets.

The control group diet had a higher iron content in the first place because of the components - vitamin and mineral premix, wheat bran, maize grain - which was not present in similar quantities in the other diet mixtures. Wheat bran is iron-rich (Farajzadeh and 
Table 4. Haematocrit (1/100 l) in the peripheral blood of piglets during the study and from published literature descriptive statistical values.

\begin{tabular}{|c|c|c|c|c|c|c|c|}
\hline Indicator & Group & Stat. value & Day 5 & Day 10 & Day 28 & Day 60 & Day 90 \\
\hline $\begin{array}{l}\text { Reference } \\
\text { range }\end{array}$ & $\begin{array}{l}\text { Egeli et al. } \\
\text { (1998) }\end{array}$ & Mean & 24 & 26 & 32 & $26-40$ & $26-40$ \\
\hline \multirow[t]{9}{*}{$(1 / 1001)$} & $\begin{array}{l}\text { Nerbas } \\
(2008)\end{array}$ & Mean & $23-43$ & $23-43$ & $23-43$ & $28-41$ & $28-41$ \\
\hline & $\begin{array}{l}\text { Kixmoller } \\
(2004)\end{array}$ & Mean & - & - & - & $29-45$ & $29-45$ \\
\hline & & Mean $( \pm \mathrm{SD})$ & $\begin{array}{l}26.88 \\
(2.86)\end{array}$ & $\begin{array}{l}22.11 \\
(4.99)\end{array}$ & $\begin{array}{l}19.47 \\
(7.63)\end{array}$ & $\begin{array}{l}31.54 \\
(2.88)\end{array}$ & $\begin{array}{l}33.82 \\
(3.47)\end{array}$ \\
\hline & $\mathrm{K}+\mathrm{P}$ & Median & 26.86 & 22.35 & 20.08 & 31.63 & 32.91 \\
\hline & & Minimum & 20.82 & 13.67 & 8.19 & 25.07 & 27.58 \\
\hline & & Maximum & 33.23 & 32.36 & 31.95 & 36.22 & 39.03 \\
\hline & & Mean $( \pm \mathrm{SD})$ & $\begin{array}{l}26.44 \\
(4.38)\end{array}$ & $\begin{array}{l}19.53 \\
(3.01)\end{array}$ & $\begin{array}{l}15.31 \\
(2.60)\end{array}$ & $\begin{array}{l}28.20 \\
(6.41)\end{array}$ & $\begin{array}{l}34.18 \\
(3.12)\end{array}$ \\
\hline & A 20 & Median & 26.17 & 19.91 & 15.23 & 26.13 & 34.37 \\
\hline & & Minimum & 17.15 & 11.44 & 10.48 & 21.87 & 27.78 \\
\hline \multirow[t]{9}{*}{ HCT } & & Maximum & 35.05 & 25.42 & 19.25 & 46.21 & 39.91 \\
\hline & & Mean $( \pm \mathrm{SD})$ & $\begin{array}{l}25.34 \\
(2.70)\end{array}$ & $\begin{array}{l}20.32 \\
(3.50)\end{array}$ & $\begin{array}{l}19.15 \\
(7.59)\end{array}$ & $\begin{array}{l}37.68 \\
(4.82)\end{array}$ & $\begin{array}{l}35.89 \\
(2.59)\end{array}$ \\
\hline & $\mathrm{A} 40$ & Median & 25.08 & 20.56 & 18.27 & 37.88 & 36.02 \\
\hline & & Minimum & 20.33 & 14 & 9.38 & 27.27 & 28.39 \\
\hline & & Maximum & 30.76 & 26.14 & 40.97 & 48.15 & 40.98 \\
\hline & & Mean $( \pm \mathrm{SD})$ & $\begin{array}{l}28.74 \\
(2.01)\end{array}$ & $\begin{array}{l}26.04 \\
(4.22)\end{array}$ & $\begin{array}{l}26.85 \\
(10.64)\end{array}$ & $\begin{array}{l}43.35 \\
(13.16)\end{array}$ & $\begin{array}{l}35.38 \\
(2.67)\end{array}$ \\
\hline & A79 & Median & 28.93 & 26.71 & 25.66 & 37.83 & 34.97 \\
\hline & & Minimum & 25.04 & 17.18 & 11.25 & 30.91 & 30.46 \\
\hline & & Maximum & 33.59 & 32.41 & 41.89 & 77.45 & 39.93 \\
\hline
\end{tabular}

HCT - haematocrit

SD - standard deviation

$\mathrm{K}+\mathrm{P}$ - control group, feed mixtures without popped amaranth grain

A20 - feed mixtures which contained $20 \%$ of heat-treated popped amaranth grain

A 40 - feed mixtures which contained $40 \%$ of heat-treated popped amaranth grain

A79 - feed mixtures which contained $79 \%$ of heat-treated popped amaranth grain

Monji 2004). Differences in total Fe accumulation by amaranth have been detected (Deutsch 1978; Makus 1984), and the bioavailability of the leaf Fe has been tested. In a comparison of 10 tropical GLV using anaemic rats, Ifon and Bassir (1978) found a range of Fe bioavailabilities from 7.7 to $36.2 \%$, and amaranth had the highest percentage of bioavailable Fe of all GLV tested. Using various in vitro simulations of gastrointestinal digestion, researchers have found between 2.8 and $53.6 \%$ of total Fe to be bioavailable in amaranth species (Reddy and Kulkarni 1986; Chawla et al. 1988; Latunde Dada 1990). However, analysis of four amaranth lines from different species for total and bioavailable $\mathrm{Fe}$ indicated that the line with the highest total Fe concentration did not have the highest bioavailable Fe concentrations (Reddy and Kulkarni 1986).

The hypothesis for the current study was that amaranth as an iron-containing supplement would have a beneficial effect on piglet growth and haematological indicators. This hypothesis can be rejected, because there was no clear improvement in red blood cell indices in this study. Nonetheless, the effect of the amaranth treatment was difficult to 
Table 5. Mean corpuscular haemoglobin concentration $(\mathrm{g} / \mathrm{l})$ in the peripheral blood of piglets during the study and from published literature - descriptive statistical values.

\begin{tabular}{|c|c|c|c|c|c|c|c|}
\hline Indicator & Group & Stat. value & Day 5 & Day 10 & Day 28 & Day 60 & Day 90 \\
\hline \multirow[t]{3}{*}{$\begin{array}{l}\text { Reference } \\
\text { range (g/l) }\end{array}$} & $\begin{array}{l}\text { Egeli et al. } \\
\text { (1998) }\end{array}$ & Mean & 306 & 302 & 336 & - & - \\
\hline & $\begin{array}{l}\text { Nerbas } \\
(2008)\end{array}$ & Mean & $\begin{array}{l}234- \\
440\end{array}$ & $\begin{array}{l}234- \\
440\end{array}$ & $\begin{array}{l}234- \\
440\end{array}$ & $\begin{array}{l}284- \\
351\end{array}$ & - \\
\hline & $\begin{array}{l}\text { Kixmoller } \\
(2004)\end{array}$ & Mean & - & - & - & $\begin{array}{l}306- \\
355 \\
\end{array}$ & $\begin{array}{l}306- \\
355 \\
\end{array}$ \\
\hline \multirow{16}{*}{$\mathrm{MCHC}$} & \multirow{4}{*}{$\mathrm{K}+\mathrm{P}$} & Mean $( \pm \mathrm{SD})$ & $\begin{array}{l}317.35 \\
(11.88)\end{array}$ & $\begin{array}{l}307.12 \\
(10.10)\end{array}$ & $\begin{array}{l}311.28 \\
(30.87)\end{array}$ & $\begin{array}{l}308.68 \\
(9.26)\end{array}$ & $\begin{array}{l}314 \\
(10.99)\end{array}$ \\
\hline & & Median & 315 & 305 & 305.50 & 306 & 312.50 \\
\hline & & Minimum & 294 & 282 & 276 & 290 & 296 \\
\hline & & Maximum & 340 & 330 & 421 & 325 & 334 \\
\hline & \multirow{4}{*}{$\mathrm{A} 20$} & Mean $( \pm \mathrm{SD})$ & $\begin{array}{l}319.93 \\
(15.72)\end{array}$ & $\begin{array}{l}320.16 \\
(17.84)\end{array}$ & $\begin{array}{l}309.36 \\
(14.18)\end{array}$ & $\begin{array}{l}308.23 \\
(22.34)\end{array}$ & $\begin{array}{l}315.47 \\
(11.96)\end{array}$ \\
\hline & & Median & 317.50 & 317 & 306 & 310 & 314 \\
\hline & & Minimum & 295 & 287 & 276 & 239 & 294 \\
\hline & & Maximum & 375 & 365 & 341 & 341 & 351 \\
\hline & \multirow{4}{*}{ A40 } & Mean $( \pm \mathrm{SD})$ & $\begin{array}{l}305.64 \\
(14.92)\end{array}$ & $\begin{array}{l}325.96 \\
(17.80)\end{array}$ & $\begin{array}{l}304.47 \\
(59.40)\end{array}$ & $\begin{array}{l}313.62 \\
(56.04)\end{array}$ & $\begin{array}{l}301.84 \\
(9.71)\end{array}$ \\
\hline & & Median & 303 & 327 & 310 & 287 & 301 \\
\hline & & Minimum & 287 & 292 & 84 & 241 & 284 \\
\hline & & Maximum & 353 & 377 & 386 & 454 & 321 \\
\hline & \multirow{4}{*}{ A79 } & Mean $( \pm \mathrm{SD})$ & $\begin{array}{l}295.88 \\
(9.72)\end{array}$ & $\begin{array}{l}312.81 \\
(12.02)\end{array}$ & $\begin{array}{l}301.80 \\
(31.48)\end{array}$ & $\begin{array}{l}274.50 \\
(70.37)\end{array}$ & $\begin{array}{l}307.41 \\
(10.11)\end{array}$ \\
\hline & & Median & 295.50 & 310 & 300 & 288.50 & 306 \\
\hline & & Minimum & 273 & 292 & 267 & 160 & 290 \\
\hline & & Maximum & 317 & 342 & 405 & 378 & 327 \\
\hline
\end{tabular}

MCHC - mean corpuscular haemoglobin concentration

$\mathrm{SD}$ - standard deviation

$\mathrm{K}+\mathrm{P}$ - control group, feed mixtures without popped amaranth grain

A20 - feed mixtures which contained $20 \%$ of heat-treated popped amaranth grain

A40 - feed mixtures which contained $40 \%$ of heat-treated popped amaranth grain

A79 - feed mixtures which contained $79 \%$ of heat-treated popped amaranth grain

assess, because several piglets of the control and the PAG-fed piglets showed laboratory findings of anaemia, but with a high individual variablitity. Iron was not administered to any piglets in the study, so that the haematological findings are in accordance with other experimental studies and findings reported in literature. Iron deficiency can be diagnosed by an $\mathrm{MCHC}<300 \mathrm{~g} / \mathrm{l}$, which was found in several pigs on different sampling times in our study. Pigs were kept in closed pens, so that iron intake by ingestion of soil could be excluded. The genetic background of the pigs was the same as in most commercial farms in Serbia. The litter sizes, being from 10 to 12 piglets, were optimal, as the sows are able to produce sufficient colostrum, and piglet milk intake is guaranteed. Anaemia is less often seen in piglets from small litters.

Zraly et al. (2004) concluded that amaranth, in the form of both grain and dried surface biomass, is a suitable source of nutrients to augment the diet of pigs, after components of animal origin have been prohibited. Considering the high biological value of amaranth 
Table 6. Significant differences in all groups in selected indicators between different sampling times.

\begin{tabular}{|c|c|c|}
\hline Indicator & Comparison of sampling times & $P$ value \\
\hline \multirow[t]{2}{*}{$\overline{\mathrm{MCHC}(\mathrm{g} / \mathrm{l})}$} & day 5 - day 10 & 0.006 \\
\hline & day 10 - day 90 & 0.02 \\
\hline \multirow[t]{6}{*}{$\mathrm{RBC}(\mathrm{T} / \mathrm{l})$} & day 5 - day 60 & \\
\hline & day 5 - day 90 & \\
\hline & day 10 - day 60 & \\
\hline & day 10 - day 90 & $<0.001$ \\
\hline & day 28 - day 60 & \\
\hline & day 28 - day 90 & \\
\hline \multirow[t]{8}{*}{ HCT (1/100 l) } & day 5 - day 10 & \\
\hline & day 5 - day 28 & \\
\hline & day 5 - day 60 & \\
\hline & day 5 - day 90 & \\
\hline & day 10 - day 60 & $<0.001$ \\
\hline & day 10 - day 90 & \\
\hline & day 28 - day 60 & \\
\hline & day 28 - day 90 & \\
\hline \multirow[t]{8}{*}{$\overline{\mathrm{Hb}(\mathrm{g} / \mathrm{l})}$} & day 5 - day 10 & \\
\hline & day 5 - day 28 & \\
\hline & day 5 - day 60 & \\
\hline & day 5 - day 90 & \\
\hline & day 10 - day 60 & $<0.001$ \\
\hline & day 10 - day 90 & \\
\hline & day 28 - day 60 & \\
\hline & day 28 - day 90 & \\
\hline
\end{tabular}

MCHC - mean corpuscular haemoglobin concentration

$\mathrm{RBC}$ - red blood cell count

HCT - haematocrit

HB - blood haemoglobin concentration

protein, favourable amino acid composition and dietary fibre content, it can be presumed that amaranth inclusion in feed diets for fattening pigs may partially solve the problem of animal protein replacement in the diets for monogastric animals. The results obtained in the present study are comparable with the data obtained by evaluation of growth performance of pigs, feed conversion, health status, carcass and meat quality, indicating that animal protein may be replaced with the vegetable protein amaranth (Zraly et al. 2004, 2006). However, the cost-benefit analysis in the current study showed that supplementation of amaranth in piglet feed cannot be recommended. It is evident that the costs of amaranth mixtures fed to the three piglet groups were higher compared to the cost of the diet of the control piglets, even if the reduced costs of not administering iron-dextran were taken into account. The increased cost of feeding amaranth means it is unsuitable for use as a routine supplement on pig farms.

It should be taken into account that the costs of conventional piglet diets mostly depend on the price of corn, given it comprises the largest share in the diets, but it also suffers from the largest price variations in the market. In the event that the prices of corn and soybean meal further increase, amaranth as an alternative feed component might become of greater interest for pig production. 
Table 7. Growth performance of pigs fed different diets - mean weight $(\mathrm{kg})$ per group.

\begin{tabular}{|c|c|c|c|c|c|c|c|c|c|c|c|}
\hline \multirow[t]{2}{*}{$\begin{array}{l}\text { Day } \\
\text { of life/ } \\
\text { Group } \\
\text { of piglets }\end{array}$} & \multicolumn{2}{|c|}{$\begin{array}{l}\text { Reference } \\
\text { value } \\
\text { (Vidovic } \\
\text { et al. 2011) }\end{array}$} & \multirow{2}{*}{$\begin{array}{c}\text { Reference } \\
\text { value } \\
\text { (Knezic } \\
2013) \\
\text { BWG }\end{array}$} & \multicolumn{2}{|c|}{$\begin{array}{c}\text { Diet } 1 \\
\text { (group “ } \mathrm{K}+\mathrm{P} ”) \\
\text { Mean }( \pm \mathrm{SD})\end{array}$} & \multicolumn{2}{|c|}{$\begin{array}{c}\text { Diet } 2 \\
\text { (group A20) } \\
\text { Mean }( \pm \text { SD) }\end{array}$} & \multicolumn{2}{|c|}{$\begin{array}{c}\text { Diet } 3 \\
\text { (group A40) } \\
\text { Mean }( \pm \text { SD) }\end{array}$} & \multicolumn{2}{|c|}{$\begin{array}{c}\text { Diet 4 } \\
\text { (group A79) } \\
\text { Mean }( \pm \text { SD) }\end{array}$} \\
\hline & BWG & DWG & & BWG & DWG & BWG & DWG & BWG & DWG & BWG & DWG \\
\hline Day 5 & 2.2 & & $\begin{array}{c}2.43 \\
(0.64)\end{array}$ & $\begin{array}{l}2.2 \\
(0.32)\end{array}$ & & $\begin{array}{c}2.18 \\
(0.42)\end{array}$ & & $\begin{array}{c}2.06 \\
(0.44)\end{array}$ & & $\begin{array}{c}2.0 \\
(0.5)\end{array}$ & \\
\hline $\begin{array}{l}6-10 \\
(5 \text { days })\end{array}$ & & 0.28 & & & $\begin{array}{c}0.32 \\
(0.084)\end{array}$ & & $\begin{array}{c}0.27 \\
(0.06)\end{array}$ & & $\begin{array}{c}0.26 \\
0.058)\end{array}$ & & $\begin{array}{c}0.23 \\
(0.074)\end{array}$ \\
\hline Day 10 & 3.6 & & $\begin{array}{c}5.04 \\
(1.28)\end{array}$ & $\begin{array}{c}3.84 \\
(0.74)\end{array}$ & & $\begin{array}{c}3.56 \\
(0.72)\end{array}$ & & $\begin{array}{c}3.36 \\
(0.73)\end{array}$ & & $\begin{array}{c}3.16 \\
(0.87)\end{array}$ & \\
\hline $\begin{array}{l}11-28 \\
\text { (17 days) }\end{array}$ & & 0.17 & & & $\begin{array}{c}0.16 \\
(0.035)\end{array}$ & & $\begin{array}{c}0.13 \\
(0.04)\end{array}$ & & $\begin{array}{l}* 0.17 \\
0.042)\end{array}$ & & $\begin{array}{l}* 0.17 \\
(0.045)\end{array}$ \\
\hline Day 28 & 6.5 & & $\begin{array}{c}7.48 \\
(1.94)\end{array}$ & $\begin{array}{c}6.64 \\
(1.34)\end{array}$ & & $\begin{array}{c}5.93 \\
(1.41)\end{array}$ & & $\begin{array}{c}6.33 \\
(1.08)\end{array}$ & & $\begin{array}{c}6.05 \\
(1.64)\end{array}$ & \\
\hline $\begin{array}{l}29-60 \\
\text { (31 days) }\end{array}$ & & 0.30 & & & $\begin{array}{c}0.21 \\
(0.048)\end{array}$ & & $\begin{array}{c}0.16 \\
(0.059)\end{array}$ & & $\begin{array}{c}0.17 \\
0.032)\end{array}$ & & $\begin{array}{c}0.19 \\
(0.027)\end{array}$ \\
\hline Day 60 & 16 & & $\begin{array}{l}13.50 \\
(3.23)\end{array}$ & $\begin{array}{l}13.39 \\
(2.85)\end{array}$ & & $\begin{array}{l}11.1 \\
(3.24)\end{array}$ & & $\begin{array}{l}11.8 \\
(2.09)\end{array}$ & & $\begin{array}{l}11.97 \\
(2.48)\end{array}$ & \\
\hline $\begin{array}{l}61-90 \\
\text { (29 days) }\end{array}$ & & 0.51 & & & $\begin{array}{c}0.44 \\
(0.091)\end{array}$ & & $\begin{array}{c}0.44 \\
(0.10)\end{array}$ & & $\begin{array}{l}* 0.58 \\
(0.10)\end{array}$ & & $\begin{array}{c}0.47 \\
(0.10)\end{array}$ \\
\hline Day 90 & 31 & & $\begin{array}{l}30.56 \\
(5.34)\end{array}$ & $\begin{array}{c}26.28 \\
(5.5)\end{array}$ & & $\begin{array}{c}24.09 \\
(6.67)\end{array}$ & & $\begin{array}{l}28.77 \\
(5.10)\end{array}$ & & $\begin{array}{l}25.73 \\
(5.40)\end{array}$ & \\
\hline
\end{tabular}

BWG - body weight gain

DWG - daily weight gain

SD - standard deviation

*Significant difference between experimental and control group.

Differences in haematological indices which occurred between groups of piglets fed with amaranth as well as the control group of piglets were inconsistent and of minor practical impact. Also, only small significant differences in the mean daily weight gain were found between the groups of piglets, and these were not consistent. Iron deficiency in growing pigs cannot be compensated by feeding diets with Amaranthus cruentus as an iron supplement. Common application of iron dextran to piglets is the most effective way to prevent anaemia in piglets. The beneficial effects of an amaranth diet are in no relation to the costs and so far cannot be recommended for field conditions.

\section{Acknowledgements}

The present work is part of the research done in the scientific projects III-46005 and TR-31084 granted by the Serbian Ministry of Education and Science.

\section{References}

Bartkowiak A, Skiba T, Kroliczewska B 2007: Level of selected lipid fractions in eggyolk of hens fed with fodders supplemented with amaranth seeds. Pol J Food Nutr Sci 57: 3-6

Chawla S, Saxena A, Seshadri S 1988: In-vitro availability of iron in various green leafy vegetables. J Sci Food Agric 46: 125-127

Correa AD, Jokl L, Carlsson R 1986: Chemical constituents, in vitro protein digestibility, and presence of antinutritional substances in amaranth grains. Arch Lat Nutr 36: 319-326 
Deutsch JA 1978: Genetic variation of yield and nutritional value of several Amaranthus species used as leafy vegetables. Diss Abstr Int B Sci Engng 38: 3969-B

Dietzfelbinger H 1987: Bioavailability of bi- and trivalent oral iron preparations. Investigations of iron absorption by postabsorption serum iron concentrations curves. Arzneim-Forsch 37: 107-112

Dubansky V, Zizlavsky M, Chloupek J 1997: Impaired cellular and humoral immunity of piglets as consequences of incorrect application of $\mathrm{Fe}$ (in Czech). Veterinarstvi 10: 413-417

Egeli AK, Framstad T, Morberg H 1998: Clinical biochemistry, haematology and body weight in piglets. Acta Vet Scand 39: 381-393

Egeli AK, Framstad T 1998: Effect of oral starter dose of iron on haematology and weight gain in piglets having voluntary access to glutamic acid-chelated iron solution. Acta Vet Scand 39: 359-365

FAO (Food and Agriculture Organization) 1980: Manuals of food quality control, 2: Additives, contaminants, techniques. FAO Food and Nutrition Paper, Rome, 14/2.

Farajzadeh MA, Monji AB 2004: Adsorption characteristics of wheat bran towards heavy metal cations. Sep Purif Technol 138: 197-207

Ferreira TA, Areas JAG 2010: Calcium bioavailability of raw and extruded amaranth grains. Cienc Tecnol Aliment Campinas 30: 532-538

Heinritzi K, Plonait H 1997: Blood diseases. In: H Plonait, K Bickhardt (Eds): Textbook of Pig Diseases, $2^{\text {nd }}$ edn (in German), Parey Buchverlag Berlin, 190 p.

Holmgren N 1996: Polyarthritis in piglets caused by iron dextran. In: Proceedings of the $14^{\text {th }}$ IPVS Congress, Bologna, Italy 14: 306

Ifon ET, Bassir O 1978: The nutritive value of some Nigerian leafy green vegetables. Part I. Vitamin and mineral contents. Food Chem 4: 263-267

Imeri A, Flores R, Elias L, Bressani R 1987: The effect of processing and supplementation with amino acids on the protein quality of amaranth (Amaranthus caudatus). Arch Latinoam Nutr 37: 160-173

Kixmoller M 2004: Diagnostic laboratory reference ranges for different breeds of pigs as well as histopathological and immunohistochemical examination of brains of older sows and boars for transmissible spongiform encephalopathy in the framework of TSE study (in German). München, Ludwig-Maximilians-Univ Tierärztl Fak Diss. Available at: chrome-extension://oemmndcbldboiebfnladdacbdfmadadm/http://d-nb. info/99235739X/34. Accessed July 15, 2014

Knezic V 2013: The growth rate of piglets in the period from birth to the age of 90 days (in Croatian). Graduation thesis, Faculty of agriculture, University of Zagreb, Croatia. Available at: https://bib.irb.hr/datoteka/633739. Diplomski_Knezic.pdf. Accessed: July 17, 2014

Kroliczewska B, Zawadzki W, Bartkowiak A, Skiba T 2008: The level of selected blood indicators of laying hens fed with addition of amaranth grain, EJPAU 11. Article no 18. Available at: www.ejpau.media.pl/volume11/ issue2/art-18.html. Accessed: February 5, 2011

Latunde Dada GO 1990: Effect of processing on iron level in and availability from some Nigerian vegetables. J Sci Food Agric 53: 355-361

Lehmann JW 2001: Anemia: A major medical problem in the world. Eur Clin Lab 20: 26-30

Makus DJ 1984: Evaluation of amaranth as a potential greens crop in the mid south. Hort Science 19: 881-883

Nerbas E 2008: Update of blood indices in pigs (in German). Inaugural-Dissertation zum Dr. med. vet., Tierärztliche Hochschule Hannover. Available at: chrome-extension://oemmndcbldboiebfnladdacbdfmadadm/ http://d-nb.info/99235739X/34. Accessed: July 16, 2014

Pisarikova B, Zraly Z, Kracmar S, Trckova M, Herzig I 2005: Nutritional value of amaranth (genus Amaranthus L.), grain in diets for broiler chickens. Czech J Anim Sci 50: 568-573

Rangarajan A, Chenoweth WA, Kelly JF, Agee KM 1998: Iron bioavailability from Amaranthus species: 2- Evaluation using haemoglobin repletion in anemic rats. J Sci Food Agr 78: 274-280

Reddy NS, Kulkarni KS 1986: Availability of iron from some uncommon edible green leafy vegetables determined by in vitro method. Nutr Rep Int 34: 859-861

Sokol JL, Bobel BK, Fabijanska M, Bekta M 2001: Preliminary results on the influence of amaranth seeds on carcass and meat quality of fatteners. J Anim Feed Sci (Suppl. 2) 10: 203-208

Svoboda M, Drabek J 2002: Effect of oral administration of $\mathrm{Fe}^{2+}$-fumarate on erythrocyte profile and growth rate of suckling Piglets. Acta Vet Brno 71: 217-222

Svoboda M, Bouda J, Drabek J, Doubek J 2004: Effect of per os iron lactate supplement on development of haematological profile of piglets in the early postnatal period. Acta Vet Brno 73: 431-436

Vidovic V, Visnjic V, Jugovic D, Punos D, Vukovic N 2011: Swine husbandry (in Serbian). Aprosim, Novi Sad, Serbia, $238 \mathrm{p}$.

Yanez E1, Zacarias I, Granger D, Vasquez M, Estevez AM 1994: Chemical and nutritional characterization of Amaranthus (Amaranthus cruentus). Arch Latinoam Nutr 44: 57-62

Zraly Z, Pisarikova B, Hudcova H, Trckova M, Herzig I 2004: Effect of feeding amaranth on growth eficiency and health of market pigs. Acta Vet Brno 73: 437-444

Zraly Z, Pisarikova B, Trckova M., Herzig I, Jozl M, Simeonovova J 2006: Effect of lupine and amaranth on growth eficiency, health, and carcass characteristics and meat quality of market pigs. Acta Vet Brno 75: $363-372$ 